\title{
地下水と川水の混合水によるアルミニウム黄銅管の応力腐食割れ*
}

\author{
下 平三郎** 佐 藤 武 明**

\section{Study on Stress Corrosion Cracking of Aluminum Brass Pipes in Mixed Water of Underground and River Water}

\section{Saburo Shimodaira and Takeaki Sato}

Aluminum brass pipes in the cooler for transformer oil have been suffered from corrosion cracking at the Numazawanuma Power Station for recent several years. Underground water and the Tadami River water are alternately used as cooling water. The static stress-corrosion test on aluminum brass pipes were carried out using underground water, cooling water for transformer oil and the Tadami River water at the Numazawanuma Power Station. The following conclusions were obtained from the results of the test.

(1) The cracking of aluminum brass pipes in the cooler is due to stress-corrosion in cooling water.

(2) The stress in stress-corrosion cracking is originated by fixing process of pipes in the cooler.

(3) A corrosive substance in cooling water

\section{1. ま え がき}

只見川水系沼沢沼発電所ではここ数年来変圧器油冷却 器用銅合金管の腐食割れ事故が引続いて起り関係者を悩 ましている。変圧器油の冷却は水冷式で冷却器の構造は

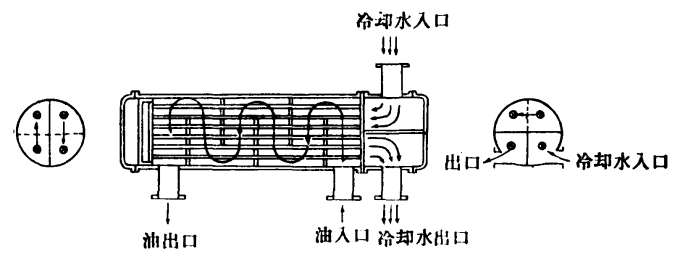

第 1 図 油冷却器の構造

第 1 図に示すようである。1 個の冷却器に銅 合 金管が 212 本ずつ使用され管の両端は管板に固定されている。 管の長さは $105 \mathrm{~cm}$ で泠却水はこの距離を 2 往復して排 出される。発電所のある只見川の右岸は沼沢沼に近いた めに地下漏水が多いので变圧器油泠却用水の大半はこの 地下漏水を利用している。本発電所の変圧器油泠却器は 冷却用水として地下水と川水を混用している点が他の発

* 昭和 34 年 11 月学振主催第 3 回防食技術研究討論会において発表

** 東北大学金属材料研究所 (仙台市片平町) may be sulfur.

(4) Stress-corrosion cracking of aluminum brass pipes in the cooler will occure at an applied stress of $2 \mathrm{~kg} / \mathrm{mm}^{2}$ in two years.

(5) Aluminum brass pipes were suffered from general corrosion by underground water, but they were almost in passive state in river water. Stress-corrosion cracking were scarcely occurred in either underground or river water. Nevertheless, stress-corrosion cracking were easily occurred in cooling water that consists of underground and river water.

(6) The form of cracks in aluminum brass pipes is perfectly identical in both case of practical use and experiment. All cracks start from pitting and they are transcrystalline.

電所と異なっている。さらにもう一つ特異な点は本発電 所のある只見川右岸一帯は硫黄鉱区であって本発電所の 上流約 $1.5 \mathrm{~km}$ の右岸に硫黄精練所があり, その廃液が 只見川に放出されていることである。本発電所用水の水 質は第 1 表に示すようである。冷却用水として地下水と

第 1 表 発電所用水の化学分析結果

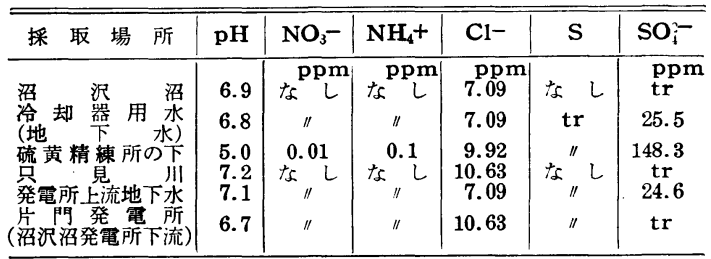

川水の使用割合(通水時間)は,たとえば次のようである。 1957 年 10 月から 1958 年 9 月までの $8,592 \mathrm{hr}$

地下水 $55 \%, 川$ 水 $34 \%$, 地下水と川水の混合水

$9 \%$ ，通水しない時間 $2 \%$

冷却器における水温と油温の例は第 2 表のようである。

本発電所は世界有数の揚水式発電所であって発電とポ ソプ揚水が 1 日数回交替に行なわれるために諸設備の使 用状態の急変がはなはだしくこのことは冷却器において 
も同様である。

第 2 表

\begin{tabular}{|c|c|c|c|c|c|c|c|c|}
\hline \multirow{2}{*}{ 冷 } & \multirow{2}{*}{ 却 } & \multirow{2}{*}{\multicolumn{2}{|c|}{ 器 }} & \multicolumn{2}{|c|}{ 水 } & 跙 ${ }^{\circ} \mathrm{C}$ & \multicolumn{2}{|c|}{ 油 温 ${ }^{\circ} \mathrm{C}$} \\
\hline & & & & 入 口 & 出 & 口 & 入口 & 出口 \\
\hline $\begin{array}{l}\# 1 . \\
\# 2 .\end{array}$ & $\begin{array}{l}\text { 冷 } \\
\text { 冷 }\end{array}$ & 却 & $\begin{array}{l}\text { 器 } \\
\text { 器 }\end{array}$ & $\begin{array}{l}21.0 \\
11.0\end{array}$ & $\begin{array}{l}26.0 \\
16.0\end{array}$ & $\begin{array}{l}\text { (只見川水) } \\
\text { (地下) }\end{array}$ & $\begin{array}{l}53.5 \\
48.0\end{array}$ & $\begin{array}{l}50.5 \\
45.0\end{array}$ \\
\hline
\end{tabular}

本発電所は 1951 年 12 月に発電を始めたが冷却管の割 れは\#1 冷却器では 1954 年 1 月に, \#2 冷却器では 1953 年 9 月に初めて発見された。その後割れが続発したため に 1954 年 9 月に 4 個の泠却器の銅合金管を全部新品に 取替えた。この更新後における銅合金管の割れ発生の様 子は第 2 図に示すようである。また割机が初めて発生す るまでの期間は第 3 表のようである。

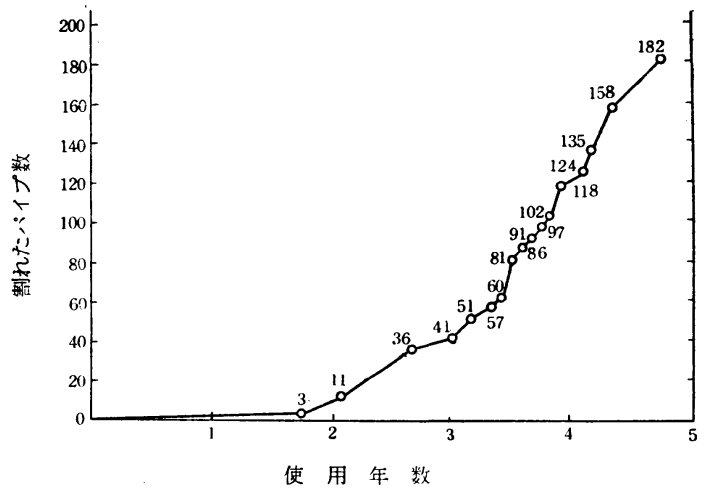

第 2 図 冷却管の割れ発生状況（添字は割んた総本数）

第 3 表

\begin{tabular}{c|c|c}
\hline 冷 却 器 番 号 & 使用開始時期 & 初めて割れが発生するまでの期間 \\
\hline II & 1956 年 11 月 & 2.1 yr \\
II & 1957 年 6 月 & 2.6 \\
II & 1956 年 11 月 & 2.1 \\
IV & 1956 年 6 月 & 1.8 \\
\hline & & 平均 2.2 \\
\hline
\end{tabular}

銅合金管総数は 848 本であるが使用開始後 4.8 年間に 182 本が割れた。従って全体の約 $22 \%$ がすでに割れた ことになる。実際にはこの割れは約 3 年間におきたもの であるから現在では毎月平均約 5 本ずつ割れている形勢 である。

冷却管の割れの原因としては応力腐食割れあるいは腐 食疲労割れが考えられるがこの場合はおそらく両者の重 畳したものでその主力は応力腐食割れであろう。応力発 生の原因としては管の製作における残留応力，管を管板 に固定するエキスパンディングの工程によって生じる残 留応力, 冷却器使用中に生じる熱的応力などが考えられ る。エキスパンディングによる残留応力は実測の結果で は張力 $2 \sim 3 \mathrm{~kg} / \mathrm{mm}^{2}$ 程度に達するものも少なくないよ うである。冷却管の割れはすべて管の長手方向に直角に
生じ割れはほとんどすべて微小な孔食から発生してい る。割れは大部分が結晶粒内割れである。

\section{2. 実 験 方 法}

実際の腐食問題の解決には必ず現場実験を行なう必要 があるが発電所現場における腐食疲労の実験あるいは熱 的応力腐食の実験は困難であるのでまず普通の静的応力 腐食の実験を行なうことにした。

第 4 表 試験用アルミニウム黄銅管の組成と寸法

\begin{tabular}{|c|c|c|c|c|c|c|c|c|}
\hline & $\mathrm{Cu}$ & $\mathrm{Fe}$ & $\mathrm{Pb}$ & As & $\mathrm{Sb}$ & Al & $\mathrm{Si}$ & $\mathrm{Zn}$ \\
\hline & 78.11 & 0.02 & $\operatorname{tr}$ & 0.05 & 0.01 & 2.00 & 0.22 & $\mathbf{R}$ \\
\hline \multirow[t]{2}{*}{ b) } & 寸 法 & & & & & & & \\
\hline & $\begin{array}{l}\text { 長 } \\
550 \mathrm{~m}\end{array}$ & & $\begin{array}{c}\text { 外 } \\
16.4\end{array}$ & & $\begin{array}{c}\text { 管 厚 } \\
1.2 \mathrm{~m}\end{array}$ & & $\begin{array}{l}\text { 実断 } \\
56.7\end{array}$ & $\begin{array}{l}\text { 口積 } \\
\mathrm{nm}^{2}{ }^{2}\end{array}$ \\
\hline
\end{tabular}

試験片は絸成，寸法および熱処理とともに冷却器用銅 合金管と全く同一のもの（第 4 表参照）を使用したが装 置の都合上管の長さを $50 \mathrm{~cm}$ とした。管はエキスパン ディングによって固定しスプリングによって荷重を加え た。*スプリングによる張力は 1 個ずつ測定して調整し た。加えた荷重の大きさは 2,5 および $8 \mathrm{~kg} / \mathrm{mm}^{2}$ の 3 段階である。同一荷重で管 4 本ずつを試験した。管内の 流速は平均 $1 \mathrm{~m} / \mathrm{sec}$ である。

発電機ベアリング油泠却器の泠却管は变圧器油泠却器 の泠却管と同一材質であるが, 1951 年使用開始以来全く 事故が起きていない。これは泠却用水が川水のみである ことと負荷が小さいことによるものと思われる。変圧器 油冷却器では既に述べたように地下水と川水を混用して いる。それで試験用水として (A) 地下水, (B) 変圧器 油冷却用水および $(\mathrm{C})$ 只見川の水を使用することにし

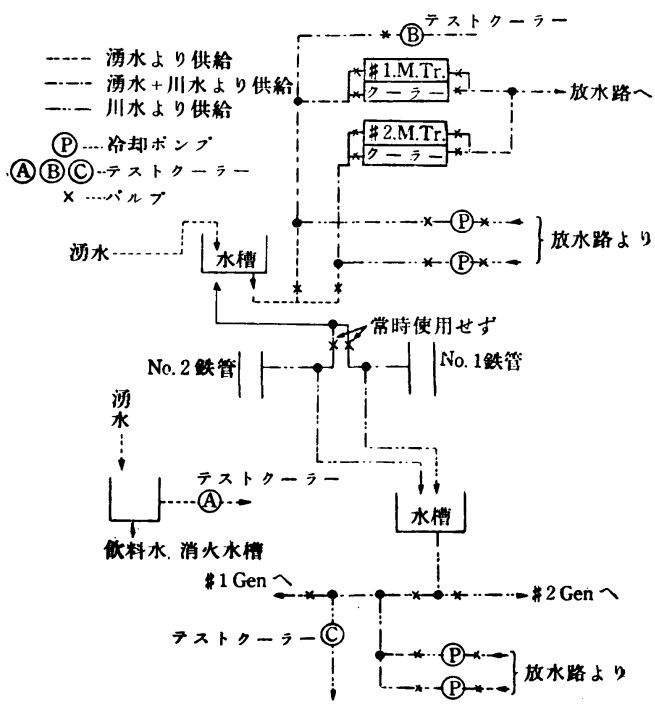

第3図応力腐食割れ試験用水系統図 
た。試験用水の系統図は第3 図に示すようである。図で (A，®および@で示してあるのが応力腐食試験装置の設 置場所である。に設置した銅合金管は通水に関する限 り冷却器内の銅合金管とほとえど同一条件の下にある。

\section{3. 実験結果と考察}

1957 年 10 月 5 日に通水を始め 1958 年 9 月 27 日に 各 荷重に执いて水の入口と出口に相当する計 2 本ずつの試 験用銅合金管を取りはずして立体顕微鏡で検査した。こ の期間の通水は第 5 表のようである。

第 5 表

\begin{tabular}{|c|c|c|c|c|}
\hline \multirow{3}{*}{$\begin{array}{c}\frac{\text { 試駼装置記号 }}{\text { (A) }} \\
\text { (B) }\end{array}$} & \multicolumn{2}{|c|}{ 試験装置設置場所 } & \multicolumn{2}{|c|}{ 通水時間 } \\
\hline & 火 & 栓 & 地 下 水 & 8,592 \\
\hline & \#1 冷 却 & 器 & 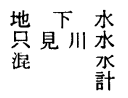 & $\begin{array}{r}4,680 \\
2,972 \\
836 \\
8,488\end{array}$ \\
\hline (C) & 発電機ベアリンク & 油冷却器 & $\begin{array}{c}\text { 只見川水 } \\
\text { 沼沼水 } \\
\text { 計 }\end{array}$ & $\begin{array}{l}7,060 \\
1,532 \\
8,592\end{array}$ \\
\hline
\end{tabular}

地下水のみを通水した@では全面腐食を蒙むってが市 肌になりその中に微小な孔食が多数発生していた。しか し割れの発生は荷重 $8 \mathrm{~kg} / \mathrm{mm}^{2}$ に至るまで全く認めら れなかった。地下水と川水を混合して使用した®，すな わち変圧器油冷却用水を通水した管は表面全体としては (®よりはるかにきれいで, 少数の微小な孔食が存在する にすぎないが，割れは荷重 $5 \mathrm{~kg} / \mathrm{mm}^{2}$ の管 2 本ともに 無数, 荷重 $8 \mathrm{~kg} / \mathrm{mm}^{2}$ の管の 1 本には約 120 , 他のもう 1 本の管には約 110 発生していた。これらの割れはほと んぞ全部が第 4 図に示寸ように，孔食から発達していた。 すなわちこの場合銅合金管の応力瓷食割れは孔食の発生 と密接な関係がある。割れは管の外側まで達したものは なかったが，木槌で軽く吒く程度の打撃でも容易に外側 まで割れた。只見川の水と沼沢沼の水(これは大部分が揚 水した只見川の水である）を通水した(C)では管の面は(B) よりさらにきれいで，孔食の発生も少なかった。割れは 荷重 $8 \mathrm{~kg} / \mathrm{mm}^{2}$ の中 1 本だけに約 30 発生した。以上は 倍率 60 倍の立体䫓微鏡で観察した結果であるが, 割れ の梁さなどについての差をみるために引張強さを測定し た。管そのままの形状から見かけの巾 $12 \mathrm{~mm}$ ，平行部 分の長さ $120 \mathrm{~mm}$ の試験片を作って試験した。試験片 は横断面が彎曲しているので測定值そのものはあまり意 味がないが，相対的な差を調べるには差支えない。結果 は第 6 表に示すように顕微鏡的観察結果とよく一致して いる。

第 6 表

\begin{tabular}{c|c|c|c}
\hline \hline 荷重 $\mathrm{kg} / \mathrm{mm}^{2}$ & (A) & B & C \\
\hline 2 & $0.793 \mathrm{t}$ & $\mathbf{0 . 7 3 1 \mathrm { t }}$ & $\mathbf{0 . 8 2 0 \mathrm { t }}$ \\
5 & $\mathbf{0 . 8 3 0}$ & $\mathbf{0 . 7 2 0}$ & $\mathbf{0 . 7 6 3}$ \\
8 & $\mathbf{0 . 8 4 0}$ & $\mathbf{0 . 5 9 7}$ & $\mathbf{0 . 8 5 0}$ \\
\hline
\end{tabular}

測定值は 4 回の平均值である。これからわかるように 地下水のみでは全面腐食を蒙むるにもかかわらず，引張 強さはほとんど变化しない。变王器油冷却用水では荷重 が大きいほど引張強さが低下し割れが哚くなることを示 している。(Cでは割れが極端に片寄っていたので割れの ある部分は引張試験に使用しなかった。

1959 年 10 月 5 日に残りの管を全部取りはずして 検査 した。通水時間は第 7 表のようである。

\section{第 7 表}

\begin{tabular}{|c|c|c|c|c|c|}
\hline 試験装置記号 & . & 通 & 水 & 間 & $\mathrm{hr}$ \\
\hline (A) & 地 & 下 & 水 & & 17,352 \\
\hline (B) & 地 & ${ }^{\mathrm{V}}$ & 永 & & 15,984 \\
\hline (c) & 只 & 覍分 & 水 & & 15,239 \\
\hline
\end{tabular}

腐食形態ならびに面の状態は 1 年経過後とほほ同様で ある。しかし割れ発生の領域は 1 年経過後より拡がり地 下水のみの場合でも荷重 $8 \mathrm{~kg} / \mathrm{mm}^{2}$ の中の 1 本に割れが 認められた。また変压器油冷却用水では荷重 $2 \mathrm{~kg} / \mathrm{mm}^{2}$ でも多数の割れが発生した。荷重 5 および $8 \mathrm{~kg} / \mathrm{mm}^{2}$ では実に多数の割れが発生した。川水のみでは 1 年経過 後と同様に荷重 $8 \mathrm{~kg} / \mathrm{mm}^{2}$ の中の 1 本に割れが 5 認 められた。試験に使用した銅合金管の本数を分母で，ま た割れが発生した管の本数を分子で示すと 2 年間の試験 結果は第 8 表のようである。

第 8 表

\begin{tabular}{|c|c|c|c|c|c|c|}
\hline \multirow{2}{*}{$\begin{array}{l}\text { 荷 重 } \\
\mathbf{k g} / \mathrm{mm}^{2}\end{array}$} & \multicolumn{2}{|c|}{ 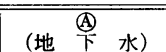 } & \multicolumn{2}{|c|}{$\begin{array}{c}\text { (B) } \\
\text { (地下水十只見川水) }\end{array}$} & \multicolumn{2}{|c|}{ (只見川水) } \\
\hline & $1 \mathrm{yr}$ 後 & $2 \mathrm{yr}$ 後 & $1 \mathrm{yr}$ 後 & $2 \mathrm{yr}$ 後 & $1 \mathrm{yr}$ 後 & $2 \mathrm{yr}$ 後 \\
\hline $\begin{array}{l}2 \\
5 \\
8\end{array}$ & $\begin{array}{l}0 / 2 \\
0 / 2 \\
0 / 2\end{array}$ & $\begin{array}{l}0 / 2 \\
0 / 2 \\
1 / 2\end{array}$ & $\begin{array}{l}0 / 2 \\
2 / 2 \\
2 / 2\end{array}$ & $\begin{array}{l}2 / 2 \\
2 / 2 \\
2 / 2\end{array}$ & $\begin{array}{l}0 / 2 \\
0 / 2 \\
1 / 2\end{array}$ & $\begin{array}{l}0 / 2 \\
0 / 2 \\
1 / 2\end{array}$ \\
\hline
\end{tabular}

2 年間の応力腐食試験によって判明した最も重要な結 果は現在変圧器油の冷却に使用している水では管の荷重 が $2 \mathrm{~kg} / \mathrm{mm}^{2}$ 程度でも約 2 年間経過すれば割れ始める ということである。銅合金管の応力腐食割れが水質によ ってこのように差を生じる原因は，現象論的には次のよ うに説明できる。銅合金管は地下水中では活性態である が川水中では受動態である。また変圧器油冷却用水中で は不完全な受動態である。もともと応力腐食割れならび に孔食は不完全な受動態領域において発生しやすいもの である。応力腐食割れの割れ伝播機構についてはまだ定 説はないが，本実験では応力が小さいので，全過程が腐 食の進行によるものと考えられる。外力によって金属表 面に塑性变形を生じ転位が移動するとき表面皮膜あるい は合金内の溶質の偏析などによって転位の移動が阻止さ れて転位が堆積すれば，そこに大きい応力が発生する。 この応力によって微視的領域における電気化学腐食反応 の活性化エネルギーが低下する。応力に基ゔく活性化エ 
ネルギーの低下を $\mathrm{E}_{\mathrm{s}}$ volt，応力がないときの腐食電流 を $\mathrm{I}_{0}$ ，応力があるときの腐食電流を I とすれば近似的 に $\mathrm{I}=\mathrm{I}_{0} \exp \left[-\alpha \mathrm{E}_{\mathrm{s}} \mathrm{F} / \mathrm{RT}\right]$ の関係がなりたつ。ここに 风はアノード反応における転位係数，F は Faraday 定 数， Rは父体定数， $\mathrm{T}$ は紿刘温度である。活性化エネル ギーの低下 $\mathrm{E}_{\mathrm{s}}$ 第一近似をとれば応力の大きさ $\mathrm{S}$ に比 例し，また破断までの寿命 $\mathrm{t}$ は $1 / \mathrm{I}$ に比例するとして よいから，上式から $\log \mathrm{t}=-\mathrm{a} S+\mathrm{b}$ の関係がえられる。 ここに $\mathrm{a}, \mathrm{b}$ は応力以外の項が一定のとき定まる定数で ある。本実験の結果では破断までの寿命はわからないが 普通のエキスパンディングの工程による残留応力でも 2 〜3 年経過すれば, 変圧器油冷却用水では㓶れが始まる

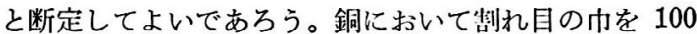
$\sim 1,000$ 原子層程度とし, 長さ $5 \mathrm{~cm}$, 深さ $1 \mathrm{~cm}$ の板 状の割れが 1 年間に腐食によって生じるとすればこの場 合銅の腐食電流は平均 $0.02 \mu \mathrm{A}$ 以下である。腐食媒が

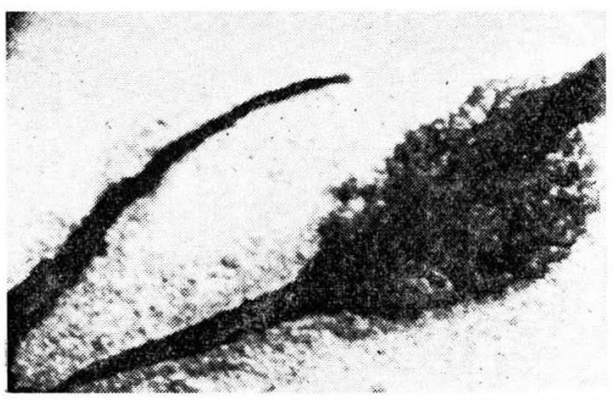

（a）実際の冷却管における孔食と割れの関係 （黑いだ円形部がれ食である $\times 30 ）$

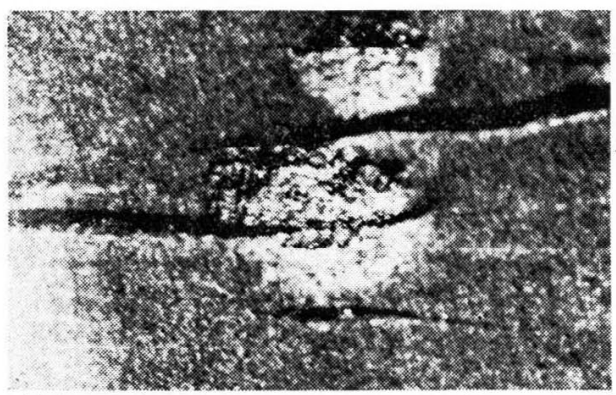

（b）応力腐食割れ試験を行なった管における 孔食と割れの関倸

（白いたた円形部がれ食である $\times 30 ）$

第 4 図
銅を分極させない性質をむつならばこの程度の腐食電流 が流れることに不合理な点は少しもない。実験室的実験 のように大きい応力下で短時間に試験片を割る場合には 制れの伝播㙨满が異なるので，その結果を直に現場の長 期にわたる割れに適用することは誤りであろう。実際の 冷却管における割れと本実験における绪れとは形態が全 く同様である(第 4 図参照)。本実験における割れもほと んどが結晶粒内制れであるがこれは合金がアルミニウム を $2 \%$ 程度含むためである。孔食の発生と応力の大きさ との関係は明らかでなかったが割れがほとてどすべて孔 食から発生していることは注目すべきである。

\section{4. ま め}

只見川水系沼沢沼発電所变圧器油冷却器冷却管（銅合 金）の腐食制れの原因を明らかにし，その対策を確立す るために応力腐食割れに関する現場実験を行ない次の結 論をえた。

（1）冷却管（アルミニウム黄錩）の制れは応力腐食割 れによるものである。

（2）冷却管における応力は管を管板に固定する組立工 程において発生する残留応力が主である。

（3）泠却用水中の腐食性物質はよくわからないが，お そらく硫黄であろう。

（4）現在俅用中の冷却用水では荷重 $2 \mathrm{~kg} / \mathrm{mm}^{2}$ 程度で も2 年経過中に制れが始まる。

（5）泠却管は地下水では全面腐食を㭬むり只見川水で はほとえど受動態を保ち，ともに忍力鹰食割れを生じ難 い。しかるに地下水と只見川水を交互に，あるいは混合 して使用する汾却用水では応力腐食制れがはなはだ起き やすい。すなわち不完全な受動態領域に置かれると応力 腐食割れがおきやすくなる。

(6) 冷却器における割れと実験における割れとは全く 同一の形態を有し，いずれも微小な孔食から発生し結唱 粒内割れである。

終りに本実験の遂行にあたり実験装置を製作して下さ った東京芝浦電気株式会社鶴見研究所金属研究課長桂伊 津美氏，試験用銅全金管を提供された住友軽金属工業株 式会社研究部ならびに長期にわたり実験を管理して下さ った東北電力株式会社沼沢沼発電所長山内広雄氏に対し て厚くお礼申上げる。（昭和 35 年 4 月 19 日受理）

\section{(1)}

与㩆庆答

\section{แแแแแแแแแแแแแแ}

西問 珪拂酸の水溶液に強いステンレスを御紹介下さ w。

出題者 日本鉱業佐賀関製鋉所 寺崎裕一

解答 珪弗酸の水溶液に耐えるステンレス鋼はありませ ん。金属で使用できるのは高珪素銅だけのようです。 解答者 森岡 進 (東北大学工学部) 